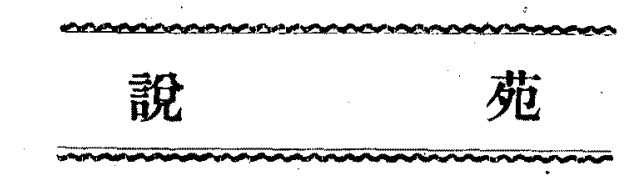

\title{
熱管理查察結果に就て
}

\author{
ゴム統制俞技郝部 沓・掛理春 \\ （昭和19年 8 月 10 日受理“昭和19年 5 月27日㩆演）
}

（1）緒論 、昭和18年12月1日より晒和19年3月31日に至万戰時熱管理非常强化期間中當統制會

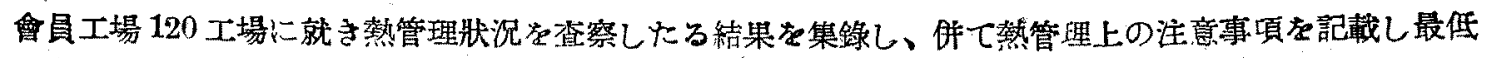

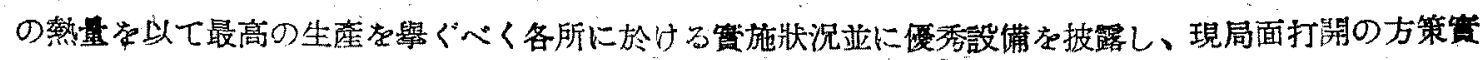

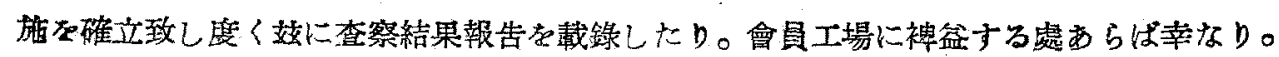

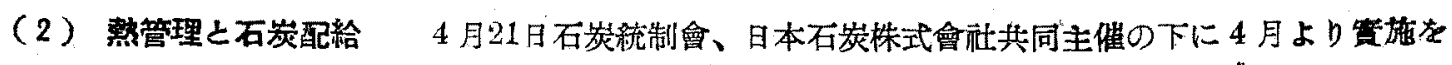
見たら標準炭配給規則に關し、說明會開催せられたり其內容次の如し。

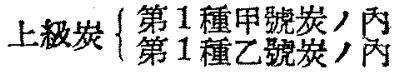
5800 力口り一以上ノも
標準炭 $\{$ 第 1 㮔甲號炭，內

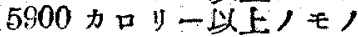
䅺準炭 $\{$ 第 1 程乙號炭及丙號炭, 内
5800 カロリ一未㴖 5100 カロリ一以上ノモノ

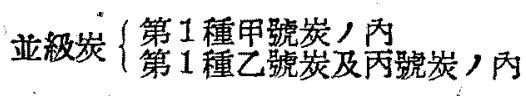
5900.カ口り一未满 5:300,力口リ一以上ノモノ

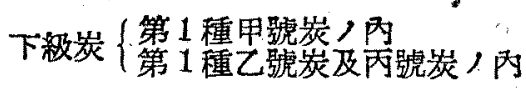

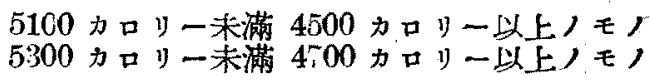
4500 カロリ一未满ノモ,
4700 カロリ一未㢼ノモノ

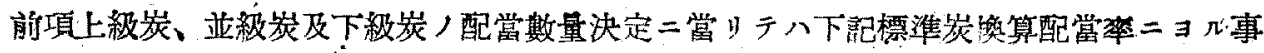

1. 上級炭二付テ八標集炭ニヨル配㗬量 1 二對シ之が配當量タ0.8トスルコト

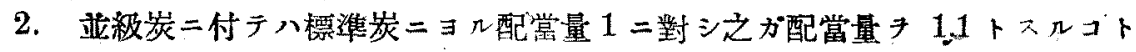

3. 下級炭二付テハ標準炭ニヨル配當量 1 二對シ之が配當量み1.4トスルコト

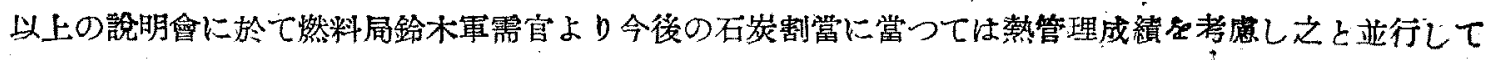

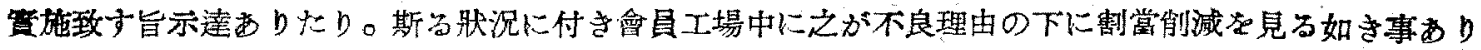

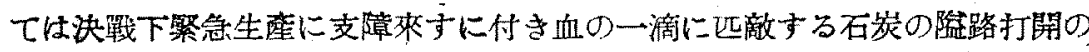
等管理の徹底强化在計られ庭雬望す。

（3）熱管理成綪 查察結果灰倀秀、優、良、可、不可の5 階級に分ち 探點せるにその成績炏の如し。

此探點は現有設備に就ての探點にして施設に相當資材を要する向に就ては 考虑せり。

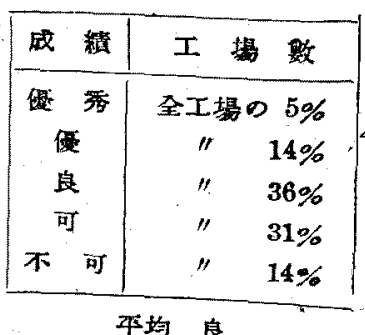

平均 息

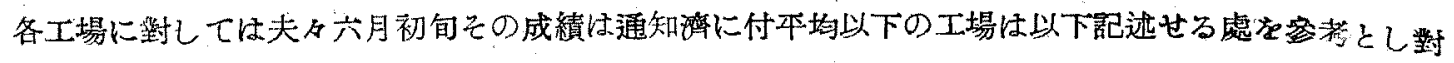
策笽施せら礼たし。 


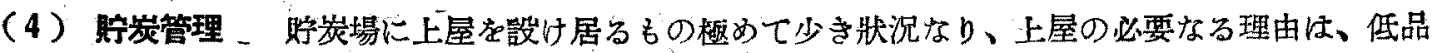

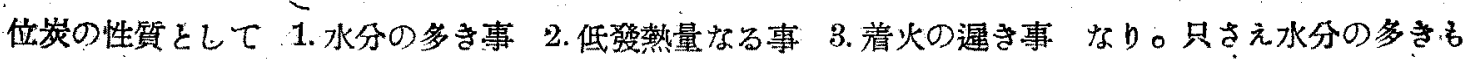

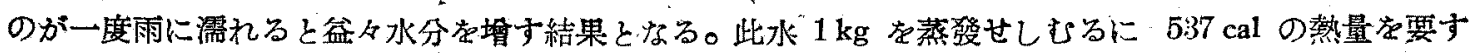

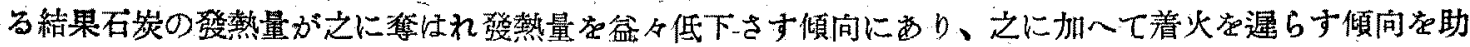

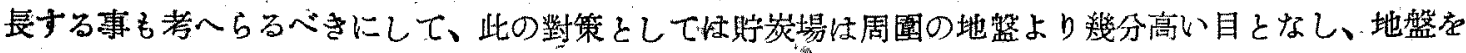
コンクリートにするか又け從來のタ、キと释する構造となし、雨水の溜るの在防止し且つ又石炭豰等多

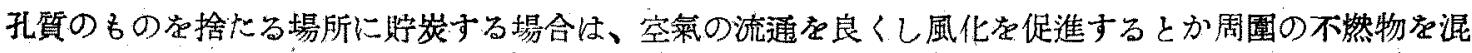

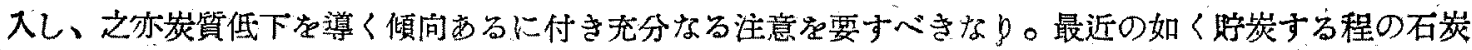

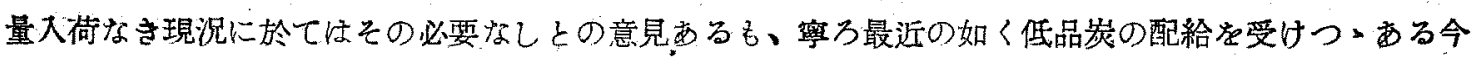
日に於ては能記理由により炭質低卡定防止する意味に於て上屋の設置を最も必要をするものなり。

理想としては炭䁈每に隔壁を設け一區劃每に一定したる量を眝炭する構造となし、汽罐場に近いるの

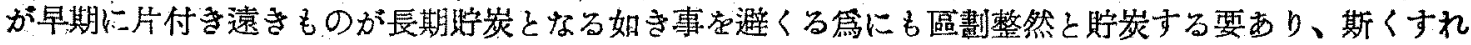

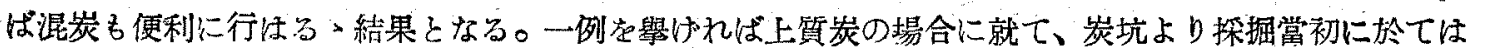
1 ケ月の聍炭に對し10\%程度の發熱量低下を見引の狀洗なり。

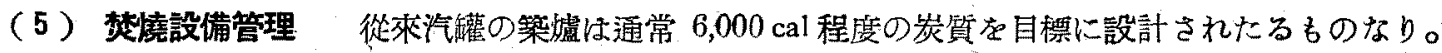
然るに最近炭質の低下著しきものなるに付き之に適する築爐となすべきなり。然鸟に此の問題に就て䨘

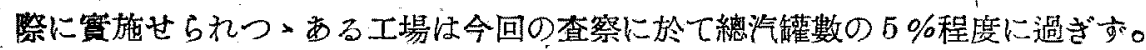

1. 實施狀況 水管式汽罐に於て注

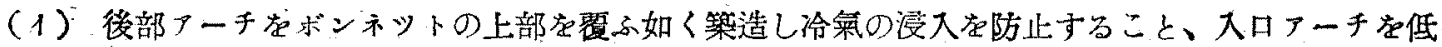

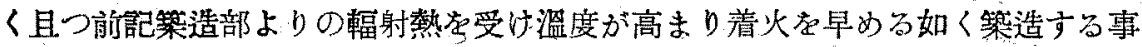

(口) 微粉炭燃燒法の採用

(ハ) 强壓通風の採用

圆筒型汽鑵に於ては

（1）爐內溫度を上昇さすべく火橋学前面傾斜にし入口に耐火煉瓦を內㖘する事

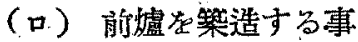

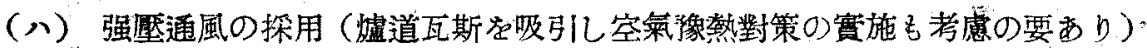

（二）投炭法の改善實施

（乐）石炭塊在 $25 \mathrm{~mm}$ 以下に碎いて焚く事

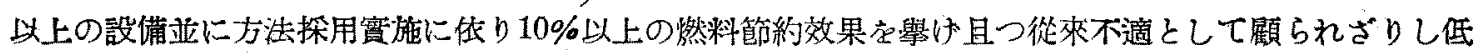

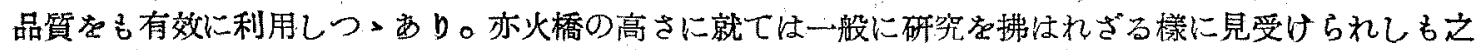

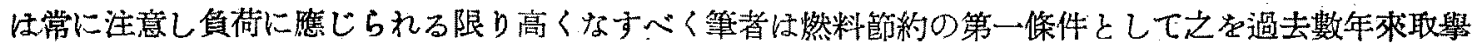

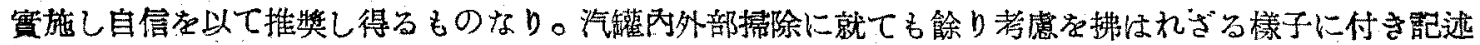

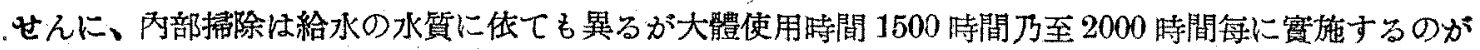

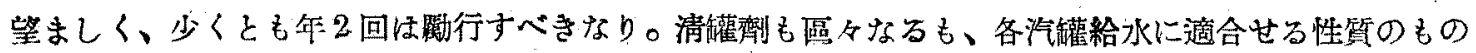




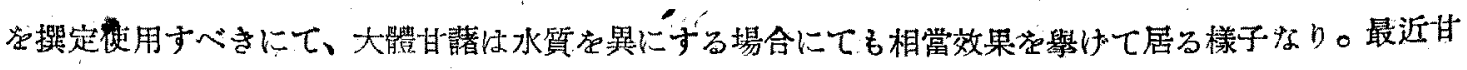

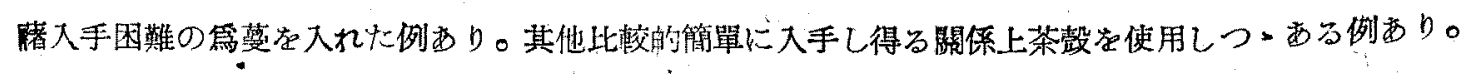

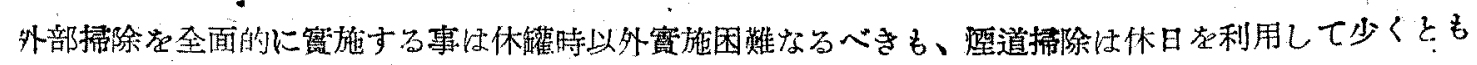
月2 回は實施すべぎり。低品炭の性質として灰分多く從て躸替回数多き結果、煙道に灰の堆皘する量

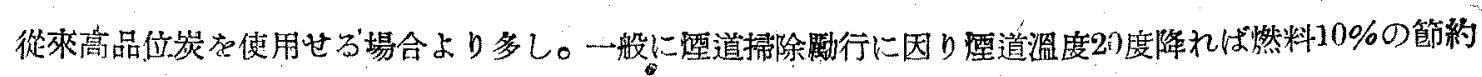
と謂は。

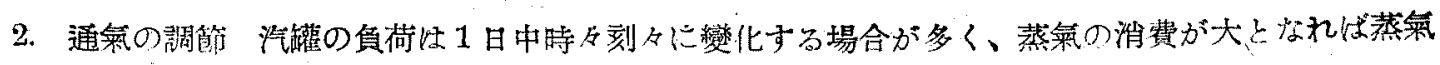

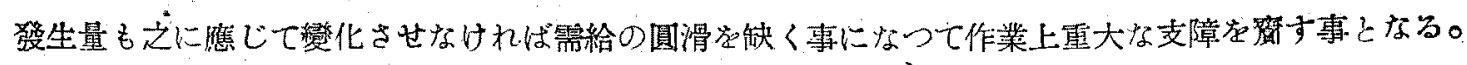

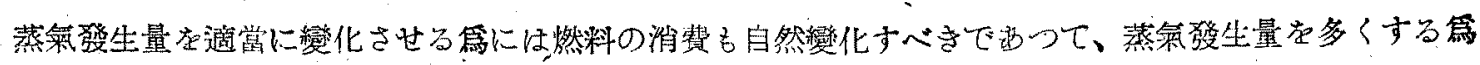
に壮多量の燃料を燃す事が必要で西るし蒸氣發生量が少なければ少量の燃料灰燃やせばよいのである。

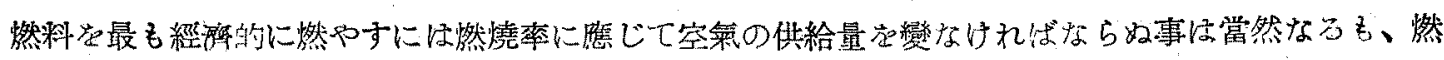
燒室內一大る空骕の量は通氣の調節に依て自由に變化させ方事が出來る。强心通氧は多量の燃料存然す

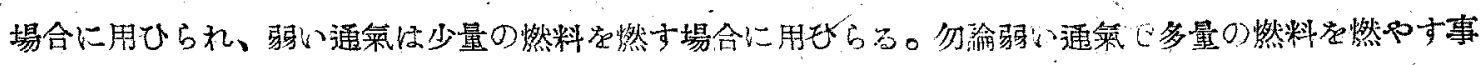

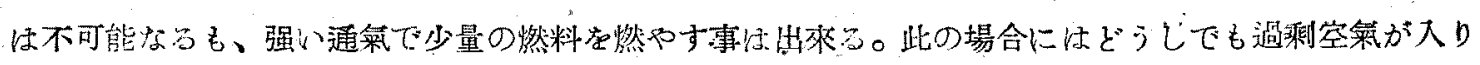

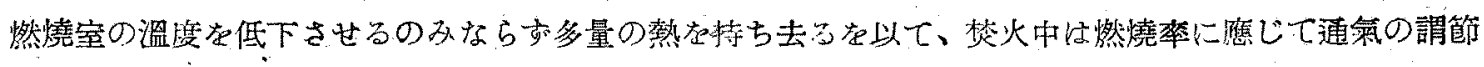

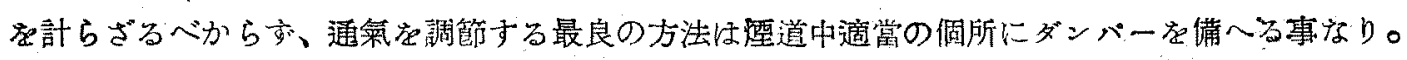

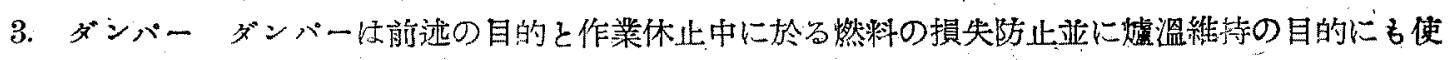

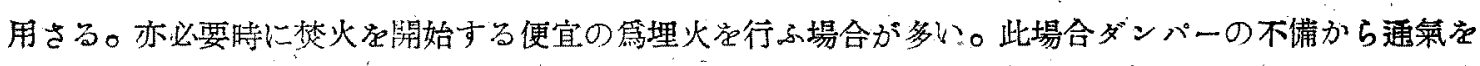

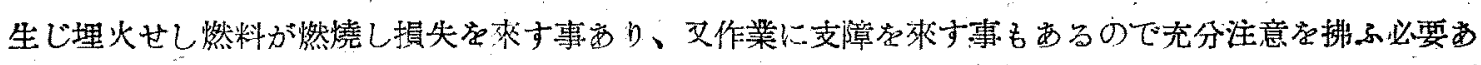

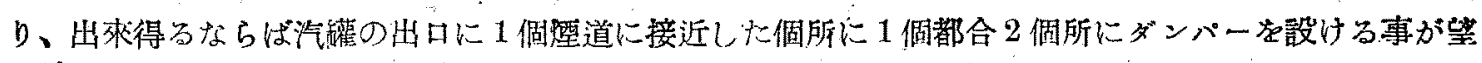

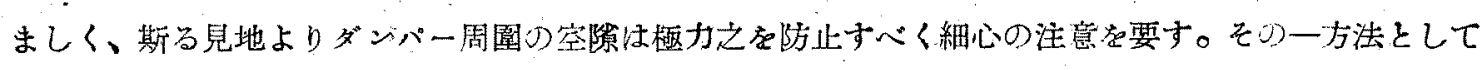

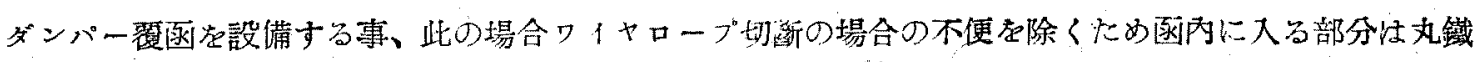

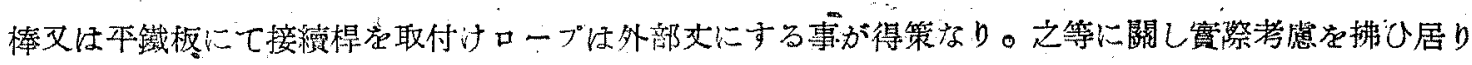
し工場数 $5 \%$ 程度なりき。

\section{(6) 設僻管理}

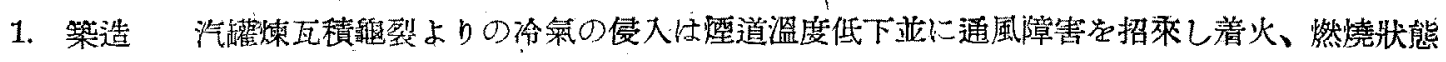
に及寸影響多し從て汽蠸效率に影響す。然るに此の點に無關心なる工場、查祭工場中59\%近くに及び、

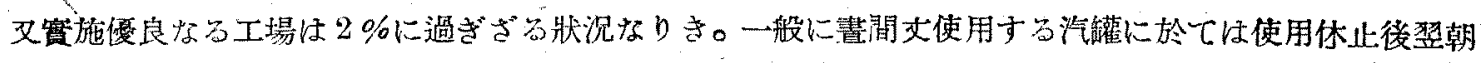

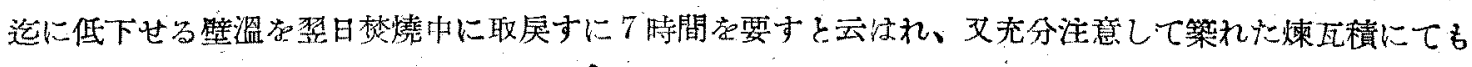

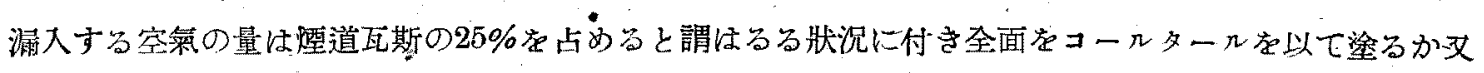
は全面保溫するとかに因て目潰する事が效果的なりとす。全面保溫は硅藻士70\%、石綿又はッタ20\%、

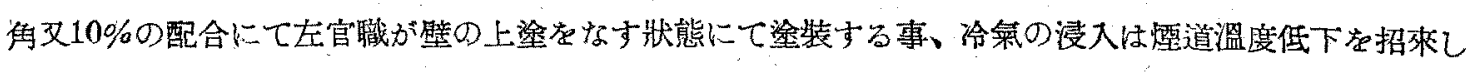

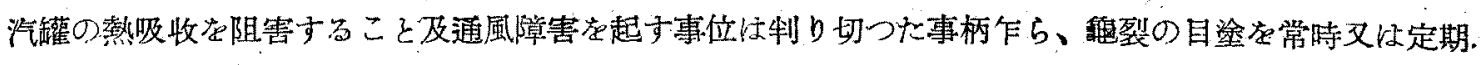
的に實施せる工場は全工場の $3 \%$ 前後と云ふ狀沉にて多くは省みられざる狀況なり。又浸入冷氧は未燃 
瓦斯と混合して二次燃燒をなし罐壁や管を過熱する事がある故煉瓦積に鼠裂の出來た場合は值にフスヘ

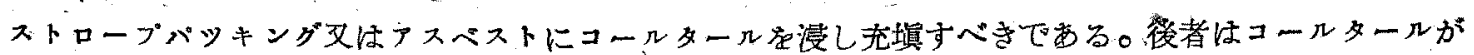
燒付き脫落防止に役立つものである。(參考)煙室の空氣漏洩は㖵空度に表はれる程度でなくとも石然消 費に約 $5 \%$ 損失在生品之謂はれて居る。

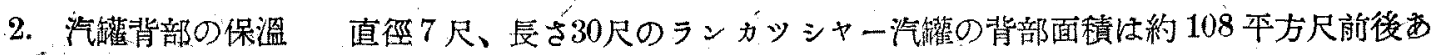
るものなり、此汽䙮の常用壓力 $7 \mathrm{~kg} / \mathrm{cm}^{2}$ 室內溫度 $21^{\circ} \mathrm{C}$ の場合放熱さる>熱量㾜汽蠸效率 $55 \%$ 發熱

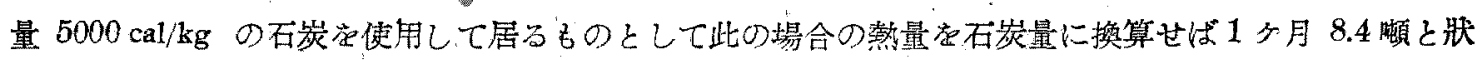

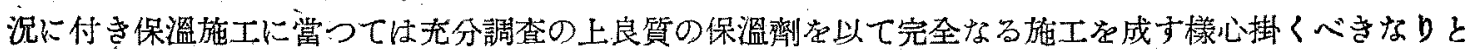
信吉。

3. 配管 太さ曲り等に就て見る汇體载にのみ捉れ非常に届曲多く技衔的に餘り考虑を拂ほれざる 工場相虽多し。文合理的太さの計算無く只配管さえすれば 蒸弌恃通するものと考心、管內の摩摖担抗に依る壓力降下 ・等在考虑せ㱛不合理配管在見受けたり。因て兹にその損失 及壓力降下を示せば第 1 表の如し。

以上の他パイプ中の壓力降下る西る事に付き配管の際法 最短距離症之る樣充分考慮すること。

\begin{tabular}{|c|c|c|c|}
\hline $90^{\circ}$ エルボー & & \multicolumn{2}{|c|}{ 管垤の30倍 } \\
\hline "I $\mathrm{T}$ 型 管 & $\ldots$ & $\prime \prime$ & 60 倍 \\
\hline ゲートハルプ & & $" \prime$ & 6倍 \\
\hline ダローブバルブ & & $" \prime$ & 60 倍 \\
\hline アングルバルブ & & $" \prime$ & 90 倍 \\
\hline 短牛睉のヘンド & . & "l & 20 倍 \\
\hline 管丝の $3 \sim 10$ 倍 & 牛俩ベンド & $\prime \prime$ & 10倍 \\
\hline
\end{tabular}

一般に配管に當てはパイプ骎 $100 \mathrm{~m}$ 當り $0.45 \mathrm{~kg} / \mathrm{cm}^{2}$ の壓力降下存許容して計算する存常とす。

4. 保溫の施工 裸パイプよりの損 失定示せ代第1表の如し。

第 1 表 襩パイプから 1 日12時閒运蒸として1ケ年間に 㙂失士西石炭量及代金

（參考）直徑 3 尺長さ 5 是の加硫萑 $3.5 \mathrm{~kg} / \mathrm{cm}^{2}$ の蒸氣壓にて使用する時上記 同一數置にて 1 㭙間 $6 \mathrm{~kg}$ の損失となる 從て 1 日 4 時間使用とすれば 1 万年間に は $8760 \mathrm{~kg}$ (262[圓180鐵)となる。斯る狀況 に付き保溫施工に當つては優良なる保溫 劑在成可〈溥く施工することが必要にし て不良保溫剂厚く施工することは避く ベきなり。厚く施工せる場合は表面積が 增して居る結果、表面接觸溫度は低いが 放熱量は增して居るるのである。良質の もの店溥く施工したる場合は表面溫度は

\begin{tabular}{|c|c|c|c|c|}
\hline \multirow{3}{*}{$\frac{ハ^{\prime} \text { 不プ陘 }}{1 / 2 "}$} & \multicolumn{4}{|c|}{ パイプ長 $30 \mathrm{~m}$ 掌り損失量 } \\
\hline & \multicolumn{2}{|c|}{ 湀蒸監力 $3.5 \mathrm{~kg} / \mathrm{cm}^{2}$} & \multicolumn{2}{|c|}{ 涘蒸㻺力 $5,25 \mathrm{~kg} / \mathrm{cm}^{2}$} \\
\hline & $426.3 \mathrm{~kg}$ & 12.78 & $493.4 \mathrm{~kg}$ & 14.80 \\
\hline $1^{\prime \prime}$ & $678.3 /$ & 20.35 & $777.0^{\circ} / 1$ & 23.30 \\
\hline $11 / 2^{\prime \prime}$ & $969.0 " /$ & 29,07 & $1110.0 " /$ & 33.30 \\
\hline $2^{\prime \prime}$ & $1201.5 / "$ & 36.05 & $1376.4 "$ & 41.29 \\
\hline $2 / 2^{\prime \prime}$ & $1511.7^{\prime \prime}$ & 45.35 & $1731.6 "$ & 51.95 \\
\hline $3^{\prime \prime}$ & $1763.7 " \prime$ & 52.91 & $2020.2 " \prime$ & 60.60 \\
\hline $31 / 2^{\prime \prime}$ & $2015.4 "$ & 60.46 . & $2308.8 "$ & 69.26 \\
\hline $4 "$ & $2286.9^{\prime \prime \prime}$ & 68.60 & $2619.6 " \prime$ & 78.52 \\
\hline
\end{tabular}

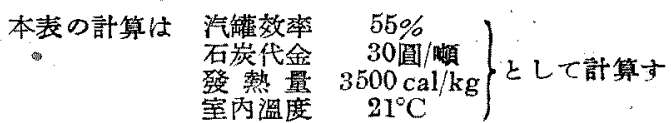
高くをも表面積が少い故放熱量は少いものはり。

ブレス及陪造機の保溫に就て見るに全然考慮されて居ら瑒及脫落して顧られざる工場あり、亦完

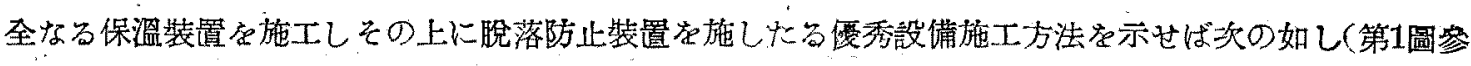


照）圖は橫型加硫罐の場合にして、小割(木材)、又は制り竹な

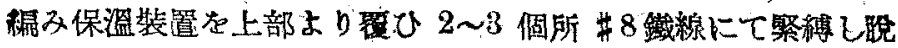

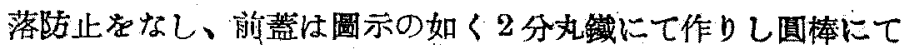

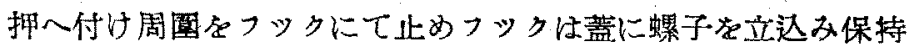
し長期使用に酎えつ>有り。

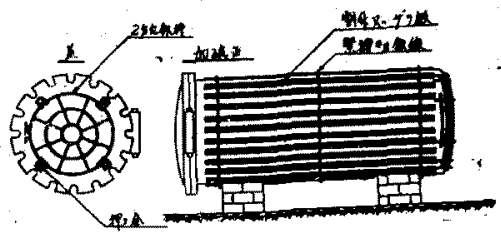

+1 回

陪造機も同樣棈造にて保溫を施工、ドウテイブレスも上部を保溫、ウオッキケース等は不綿布にて蜀

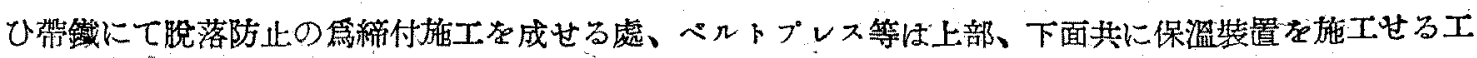
場あり、亦段プレスを內面に石綿板を張詰め外部はテックスを用ひた石函內に納め、製品出し入れの焦 前面扉は上下開閉式のもの及左右開閉式のものとすり。

何机にして子放熱防怍效果良好に て夏期作業場の溫度上昇防止去なし

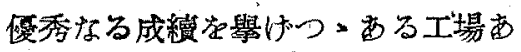
D。

總髏的に見て保溫裝置に就ては成 績不良と云ふ狀況なり。

5. 蒸釆漏 蒸彙漏は一見して 損失と刵りつ・も工場の熱管理委員 會運營組織の缺陷にて等閑に附され て居る工場多し。

保溫と蒸载漏は常識的に成し得る

第 2 表 蒸氣漏沉因る损失量表

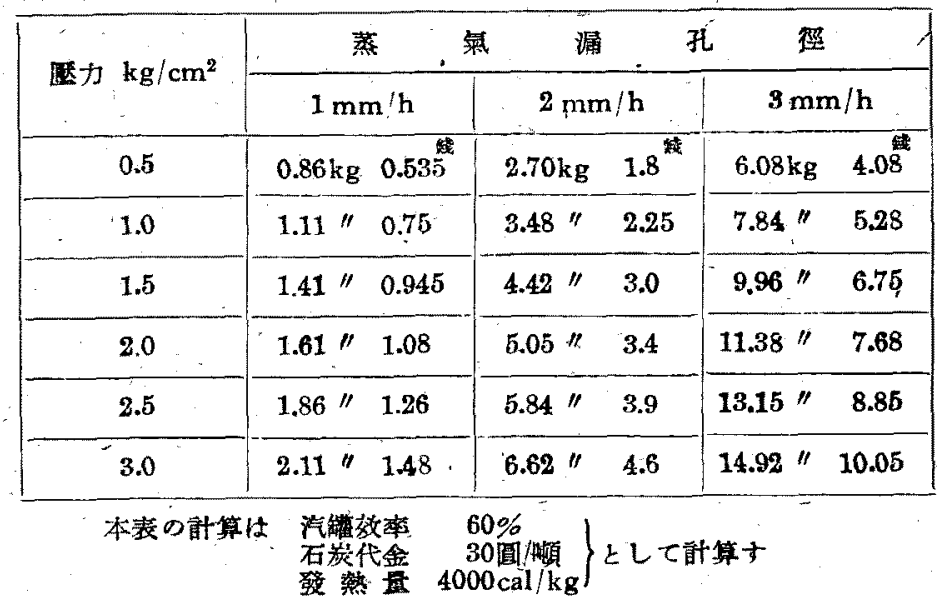

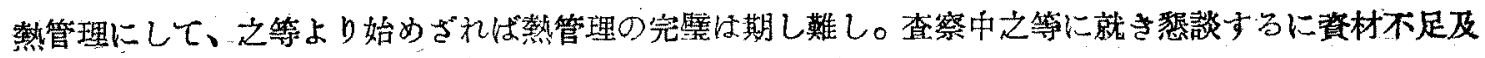

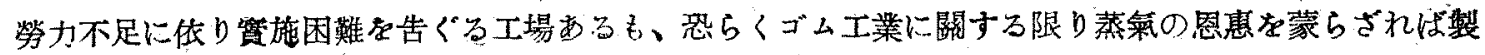

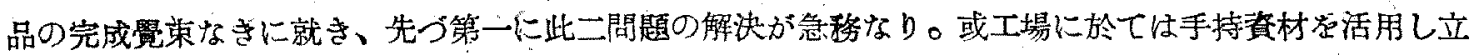

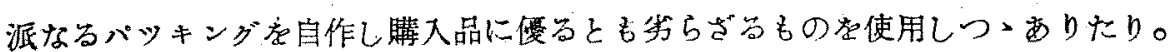

（7）使用管理，蒸策使用者は充分注意し加硫鑵の使用は手早くし不必要の時は荒を開ち冾却を防

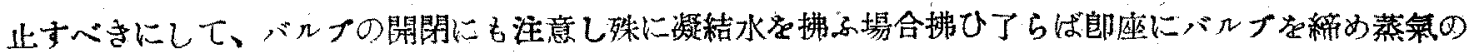
放出在防止すべき訓練在徽底さすべき存痛感せり。

（8）度蒸氣の活用切斷妻煉を容易ならしむる篇生ゴムを溫むるに加熱室に生蒸氣を使用し居る

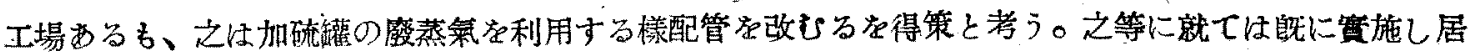
万工場 $40 \%$ に及实。

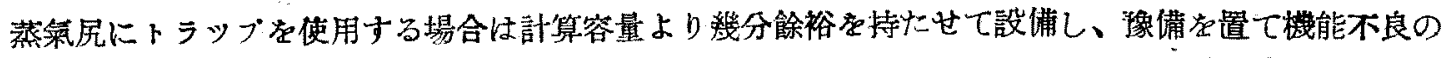
際は速に取換、修理すべきなり。

還元機は一種の大型トシッブにてブレス等よりの蒸溜水は高溫の內に回收すべきが得策なるに因り本

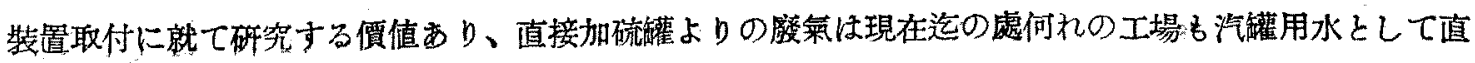




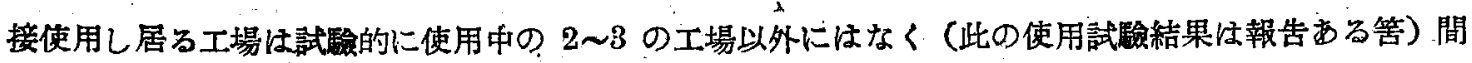

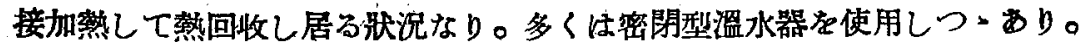

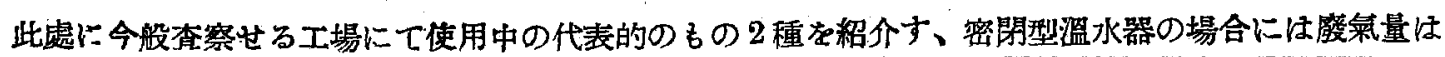

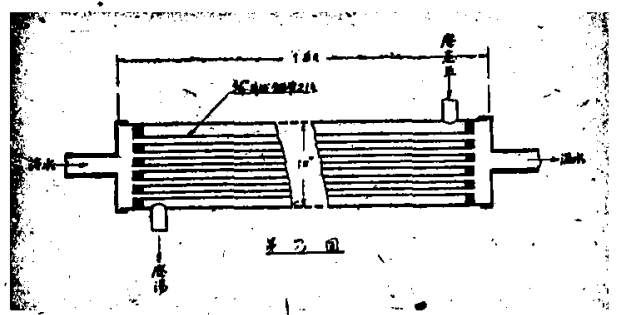

給水量の20\%を週度をする樣である。第2 圖は密閉型溫水器にして原 水溫度 $9^{\circ} \mathrm{C}$ の 6 の $90^{\circ} \mathrm{C}$ に加蓺されつ・あら。

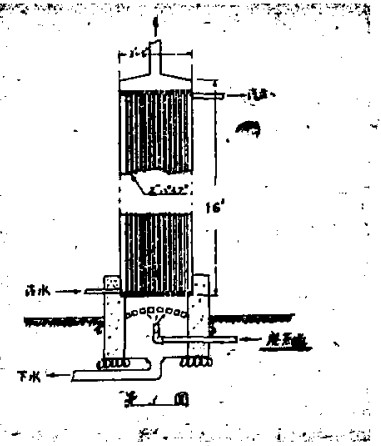

第3圖は廢蒸氣が上部バイプ內一本等に吹达まるべく撒水ショョーロの先の如く丸型鐵板に孔を穿ちた

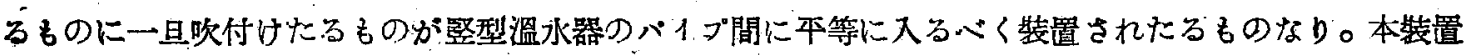

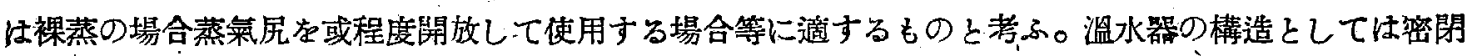
型に属す当ものに平板管波型管螺管型す。

給水溫度 $1^{\circ} \mathrm{C}$ 高まれ代大略石炭消費量は $0.16 \%$ 減少する筈なり。加硫罐 の廢楊活用配管として第4圖の如き配管すり、使用方法としでは一方の加硫 蠸の作業了り他方へその蒸氣㻺の牛分近くを活用しようと云ふ配管はり。 先つ第一に圖の左方の加硫罐在例人ば $5 \mathrm{~kg} / \mathrm{cm}^{2}$ ，の埾力で作用し加硫後は 兩加䃎權の吹込バルナ在締め連絡バルプ開く。斯く寸れば2.5 $\mathrm{kg} / \mathrm{cm}^{2} に$

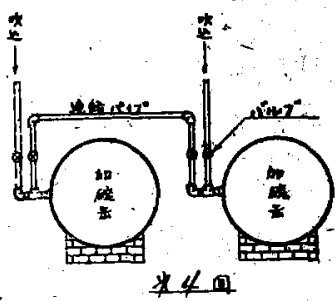
近い蒸氣は右方に移りそ狆有效に利用し得る配管なり。圖は此の連絡バイブを加硫罐の側面に取付て

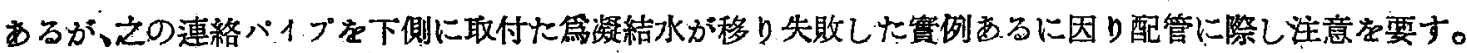

（9）熱管理と工場幹部 熱管理の必要保件として標準消費重を設定する事なり、知に研究要す べきは設備汽權の容量並に制限壓力に相應すべき慗品の受註が研究を要する事項と成る。此等の點に注 意を意ると結局無理焚在餘儀なくされ非常に燃料の損失在來すものなり。結論として工場幹部指導者に 熱意あれば下に㗢く者は必すそれに連られ狀でも着いて來べきものなるに付對策樹立の上此の輸邆力不 足の折熱管理强化徹底により時局乘切りに邁淮されて事を切望す。（完）

\section{低品位炭の焚燒法に就て}

藤會工業株式會礼 加 藤 善 '六

（昭和19年 5 月 關東支部請演）

\section{I 緒䇾}

低品位炭焚燒對策に就ては既に先侸各鹤威諸氏の理論又は筫驗的發表があるので重ねて迅べる必要る はいと思ふが、今春各工場を查祭の結果未だその處理對策存何等施行せざるは勿諭考究してさへ居ない 